\title{
The Role of Glucagon-Like Peptide 1 (GLP1) in Type 3 Diabetes: GLP-1 Controls Insulin Resistance, Neuroinflammation and Neurogenesis in the Brain
}

\author{
Choon Sang Bae and Juhyun Song * \\ Department of Anatomy, Chonnam National University Medical School, Gwangju 61469, Korea; \\ csbae@chonnam.ac.kr \\ * Correspondence: juhyunsong@chonnam.ac.kr; Tel.: +82-61-379-2706; Fax: +82-61-375-5834
}

Received: 30 October 2017; Accepted: 20 November 2017; Published: 22 November 2017

\begin{abstract}
Alzheimer's disease (AD), characterized by the aggregation of amyloid- $\beta$ (A $\beta$ ) protein and neuroinflammation, is the most common neurodegenerative disease globally. Previous studies have reported that some $\mathrm{AD}$ patients show impaired glucose utilization in brain, leading to cognitive decline. Recently, diabetes-induced dementia has been called "type 3 diabetes", based on features in common with those of type 2 diabetes and the progression of AD. Impaired glucose uptake and insulin resistance in the brain are important issues in type 3 diabetes, because these problems ultimately aggravate memory dysfunction in the brain. Glucagon-like peptide 1 (GLP-1) has been known to act as a critical controller of the glucose metabolism. Several studies have demonstrated that GLP-1 alleviates learning and memory dysfunction by enhancing the regulation of glucose in the AD brain. However, the specific actions of GLP-1 in the AD brain are not fully understood. Here, we review evidences related to the role of GLP-1 in type 3 diabetes.
\end{abstract}

Keywords: glucagon like peptide 1 (GLP-1); type 3 diabetes; diabetes-induced dementia; Alzheimer's disease (AD); insulin resistance; Amyloid beta $(\mathrm{A} \beta)$

\section{Introduction}

Alzheimer's disease (AD) as an age-related neurodegenerative disorder is not well understood in terms of etiology, even though it was first described over 100 years ago [1]. AD is characterized by extracellular accumulation of aggregated amyloid- $\beta(A \beta)$ protein, intracellular accumulation of hyper-phosphorylated tau protein, neuroinflammation, and a reduction in cerebral glucose consumption [2]. Recent studies have demonstrated that AD has a pathophysiological relationship with type 2 diabetes mellitus (T2DM), in that both involve impairment of insulin signaling and glucose metabolism [3]. Epidemiological studies have indicated that T2DM increases the risk of AD $[4,5]$. The brain has been known to regulate body energy and control food intake and body weight $[6,7]$. Additionally, the brain consumes glucose at a high rate, and uses it for propagation of action potentials and maintenance of the membrane potentials required for neuronal transmission [8,9]. AD patients show decreased glucose utilization in brain areas that are directly related to cognitive functions, including the hippocampus and cerebral cortex [10]. According to several studies, the deregulation of glucose metabolism in $\mathrm{AD}$ can be controlled by the administration of a hormone known as a potent regulator of glucose homeostasis [11] and of food intake [12], glucagon-like peptide 1 (GLP-1) [13]. The fact that administration of this peptide improves cognitive decline in patients with AD, as well as in AD mouse model $[14,15]$ suggests that deregulation of glucose in the brain is a crucial issue in the onset and progression of AD [4,5,16-18]. Here, we review recent evidence concerning the role of GLP-1 in diabetes-induced dementia. We highlight the importance of GLP-1 in the onset and progression of diabetic $\mathrm{AD}$, sometimes referred to as type 3 diabetes. 


\section{Diabetes Induced Dementia as the Type 3 Diabetes}

Recent studies have demonstrated that patients with T2DM and metabolic syndrome have elevated risk for vascular dementia and $\operatorname{AD}[19,20]$. Other studies have reported aberrant cerebral insulin homeostasis, which is called insulin resistance, in AD patients [21,22]. In the CNS, insulin is synthesized in neurons such as pyramidal and granule cells in the cerebral cortex and hippocampus [23,24]. Pancreatic insulin transported in small amounts across the blood-brain barrier (BBB) could also influence brain function [25,26]. Insulin growth factor-1 (IGF-1) and its receptor (IGF-1R) can be observed in the brain and have been related to the control of neurogenesis and synaptogenesis $[27,28]$. Deregulation of brain insulin signaling and IGF-1 signaling affects insulin resistance, energy metabolism, and lipid metabolism and results in pathological changes in the central nervous system (CNS) [29-32]. According to several studies, insulin and IGF-1 resistance can be detected in the brains of AD patients [29], but the relationship between insulin resistance and brain dysfunction remains unclear [33]. Recently, the relationship between brain insulin/IGF-1 signaling impairment and $\mathrm{AD}$ has been dubbed type 3 diabetes [34]. Further study of the mechanisms involved in the onset and progression of type 3 diabetes is necessary to improve our understanding of its pathology type 3 diabetes.

\section{Glucagon-Like Peptide 1 (GLP1)}

GLP-1 is an endogenous incretin hormone of 30-amino acids, produced by enteroendocrine L-cells, that influences food ingestion [35,36], enhances glucose-induced insulin secretion from pancreatic islets [37], and can act as a neuropeptide when released in the brain [38]. GLP-1 receptors (GLP-1R) exist widely throughout the brain, in areas including the hypothalamus, thalamus, hippocampus, cortex, and brainstem nucleus [39-41]. GLP-1 and other GLP-1 analogues can cross the BBB [42,43]. Because GLP-1 and its receptors exist in both the CNS and peripheral tissues, the effect of GLP-1 on energy metabolism is mediated by both the CNS and the peripheral nervous system (PNS) $[11,44,45]$. Moreover, GLP-1 is synthesized by neurons within the nucleus of the solitary tract [46,47]. These neurons have long projections to hypothalamic, thalamic, and cortical brain areas [48]. GLP-1 contributes to glycemic homeostasis and GLP1R agonists such as exendin-4, liraglutide, and lixisenatide have been approved to treat T2DM [49,50]. Furthermore, GLP-1 increases the spontaneous activity of neurons in the hippocampal CA1 region and promotes excitatory synaptic transmission in the hippocampus [51]. GLP-1 receptor knockout mice show decreased memory retention in the Morris water maze task, and the administration of GLP-1 agonists leads to improvement in learning and memory [52]. Here, given that GLP-1 could regulate glucose metabolism and potentially be used for treatment of T2DM [44,49], we focused on the role of GLP-1 in type 3 diabetes, highlighting the therapeutic importance of GLP-1 in diabetes-induced dementia.

\section{The Effect of GLP-1 in Type 3 Diabetes: GLP-1 Attenuates Neuroinflammation and Improves Neurogenesis and Insulin Sensitivity in AD}

One study suggested that GLP-1 mimetic drugs have neuroprotective, neurotrophic, and anti-inflammatory effects, which play a role in retardation of AD progression [14]. Another study demonstrated that liraglutide, a GLP-1 receptor agonist, can alleviate spatial memory dysfunction and neuroinflammation that leads to cognitive impairment [53]. GLP1 has been shown to act as a growth factor in the brain and promote neurite growth [54]. GLP-1 receptor activators stimulate the differentiation of neuronal stem cells in a manner similar to nerve growth factor, so it may inhibit brain atrophy in AD patients [55]. Additionally, GLP1 receptor agonists such as liraglutide and exendin-4 attenuate endogenous levels of amyloid beta in the brain and prevent amyloid plaque accumulation in the AD brain [42,53]. Furthermore, stimulating glucose metabolism in AD patients through the administration of GLP-1 markedly improves cognitive dysfunction in the AD brain [56,57]. In APP/PS1 mice (a mouse model of AD) brain, liraglutide and GLP-1 increase long-term potention (LTP) [42,58] and increase synaptic plasticity $[41,55,59]$. Moreover, GLP-1 has been found to improve insulin 
sensitivity $[60,61]$ and control energy metabolism $[62,63]$. Recent studies reported that GLP-1 could attenuate brain insulin resistance by decreasing c-Jun $\mathrm{N}$-terminal kinase (JNK) signaling and increasing the expression of the B-cell lymphoma 2 gene $(B c l 2)$ in the T2DM mouse [64]. One study demonstrated that liraglutide treatment in an AD mouse model triggers the activation of microglia in the brain [42]. Neurogenesis, the generation of new neurons from neuronal progenitor stem cells $[65,66]$, occurs in the subventricular zone (SVZ) of the lateral ventricles and the subgranular zone of the hippocampal $[67,68]$. According to previous results, adult neurogenesis is linked to memory function and the facilitation of LTP $[69,70]$. In the AD brain, a decrease in neurogenesis is commonly observed and aggravates the disease pathology [41,71]. Several studies found that GLP-1 receptor agonists increase the proliferation of neural progenitor cells [41] and increase neurogenesis in the dentate gyrus of the hippocampus [43]. Earlier studies reported the impaired proliferation of neural stem cell in the AD mouse model [66,72] and that GLP-1 and analogues of GLP-1 can promote neural stem cell proliferation in the brain [73,74]. GLP-1 receptor activates neurogenesis in hippocampus through mitogen activated protein kinases (MAPK) [75], leading to enhancement of learning and memory [75-77]. Collectively, GLP-1 could attenuate neuroinflammation and enhance neurogenesis and insulin resistance in diabetes-induced dementia, also known as type 3 diabetes.

\section{Conclusions}

Summing up, we suggest that GLP-1 is a good candidate for improving cognitive dysfunction in diabetes-induced dementia. First, GLP-1 could attenuate the inflammatory responses in brain caused by amyloid beta $(A \beta)$-induced oxidative stress. GLP-1 could regulate the activation of microglia and protect neurons against oxidative stress. Second, GLP-1 could promote neurogenesis in AD brain. This means that GLP-1 could stimulate the generation of new neurons to replace damaged neurons in the AD brain. Finally, GLP-1 can alleviate insulin resistance in the AD brain, suggesting that impaired glucose metabolism and insulin resistance leads to severe memory dysfunction. To conclude, our study highlights that manipulation of GLP-1 may be an effective therapy for improving AD-like pathology in diabetes-induced dementia, also known as type 3 diabetes.

Acknowledgments: This study was supported by the Brain Research Program through the National Research Foundation of Korea funded by a grant from 2016R1D1A1B03930394.

Author Contributions: Juhyun Song contributed to writing the preliminary draft of this manuscript and revised the manuscript. Choon Sang Bae contributed to writing the draft and revising manuscript as a whole.

Conflicts of Interest: The authors declare no conflict of interest.

\section{References}

1. Querfurth, H.W.; LaFerla, F.M. Alzheimer's disease. N. Engl. J. Med. 2010, 362, 329-344. [CrossRef] [PubMed]

2. LaFerla, F.M.; Green, K.N. Animal models of Alzheimer disease. Cold Spring Harb. Perspect. Med. 2012, 2, a006320. [CrossRef] [PubMed]

3. Akter, K.; Lanza, E.A.; Martin, S.A.; Myronyuk, N.; Rua, M.; Raffa, R.B. Diabetes mellitus and Alzheimer's disease: Shared pathology and treatment? Br. J. Clin. Pharmacol. 2011, 71, 365-376. [CrossRef] [PubMed]

4. Baglietto-Vargas, D.; Shi, J.; Yaeger, D.M.; Ager, R.; LaFerla, F.M. Diabetes and Alzheimer's disease crosstalk. Neurosci. Biobehav. Rev. 2016, 64, 272-287. [CrossRef] [PubMed]

5. Mamelak, M. Energy and the Alzheimer brain. Neurosci. Biobehav. Rev. 2017, 75, 297-313. [CrossRef] [PubMed]

6. Roh, E.; Song, D.K.; Kim, M.S. Emerging role of the brain in the homeostatic regulation of energy and glucose metabolism. Exp. Mol. Med. 2016, 48, e216. [CrossRef] [PubMed]

7. Roh, E.; Kim, M.S. Brain Regulation of Energy Metabolism. Endocrinol. Metab. 2016, 31, 519-524. [CrossRef] [PubMed]

8. Attwell, D.; Laughlin, S.B. An energy budget for signaling in the grey matter of the brain. J. Cereb. Blood Flow Metab. 2001, 21, 1133-1145. [CrossRef] [PubMed] 
9. Magistretti, P.J.; Pellerin, L. Metabolic coupling during activation. A cellular view. Adv. Exp. Med. Biol. 1997, 413, 161-166. [PubMed]

10. Doraiswamy, P.M.; Sperling, R.A.; Coleman, R.E.; Johnson, K.A.; Reiman, E.M.; Davis, M.D.; Grundman, M.; Sabbagh, M.N.; Sadowsky, C.H.; Fleisher, A.S.; et al. Amyloid-beta assessed by florbetapir F 18 PET and 18-month cognitive decline: A multicenter study. Neurology 2012, 79, 1636-1644. [CrossRef] [PubMed]

11. Holst, J.J. The physiology of glucagon-like peptide 1. Physiol. Rev. 2007, 87, 1409-1439. [CrossRef] [PubMed]

12. Barrera, J.G.; Jones, K.R.; Herman, J.P.; D'Alessio, D.A.; Woods, S.C.; Seeley, R.J. Hyperphagia and increased fat accumulation in two models of chronic CNS glucagon-like peptide-1 loss of function. J. Neurosci. 2011, 31, 3904-3913. [CrossRef] [PubMed]

13. Sherwood, V. WNT signaling: An emerging mediator of cancer cell metabolism? Mol. Cell. Biol. 2015, 35, 2-10. [CrossRef] [PubMed]

14. Holscher, C. Central effects of GLP-1: New opportunities for treatments of neurodegenerative diseases. J. Endocrinol. 2014, 221, T31-T41. [CrossRef] [PubMed]

15. Talbot, K.; Wang, H.Y. The nature, significance, and glucagon-like peptide-1 analog treatment of brain insulin resistance in Alzheimer's disease. Alzheimers Dement. 2014, 10, S12-S25. [CrossRef] [PubMed]

16. Peng, S.; Eidelberg, D.; Ma, Y. Brain network markers of abnormal cerebral glucose metabolism and blood flow in Parkinson's disease. Neurosci. Bull. 2014, 30, 823-837. [CrossRef] [PubMed]

17. Berti, V.; Mosconi, L.; Pupi, A. Brain: Normal variations and benign findings in fluorodeoxyglucose-PET/computed tomography imaging. PET Clin. 2014, 9, 129-140. [CrossRef] [PubMed]

18. Carpenter, K.L.; Jalloh, I.; Gallagher, C.N.; Grice, P.; Howe, D.J.; Mason, A.; Timofeev, I.; Helmy, A.; Murphy, M.P.; Menon, D.K.; et al. ${ }^{13}$ C-labelled microdialysis studies of cerebral metabolism in TBI patients. Eur. J. Pharm. Sci. 2014, 57, 87-97. [CrossRef] [PubMed]

19. Tolppanen, A.M.; Lavikainen, P.; Solomon, A.; Kivipelto, M.; Uusitupa, M.; Soininen, H.; Hartikainen, S. History of medically treated diabetes and risk of Alzheimer disease in a nationwide case-control study. Diabetes Care 2013, 36, 2015-2019. [CrossRef] [PubMed]

20. Biessels, G.J.; Strachan, M.W.; Visseren, F.L.; Kappelle, L.J.; Whitmer, R.A. Dementia and cognitive decline in type 2 diabetes and prediabetic stages: Towards targeted interventions. Lancet Diabetes Endocrinol. 2014, 2, 246-255. [CrossRef]

21. Butterfield, D.A.; Di Domenico, F.; Barone, E. Elevated risk of type 2 diabetes for development of Alzheimer disease: A key role for oxidative stress in brain. Biochim. Biophys. Acta 2014, 1842, 1693-1706. [CrossRef] [PubMed]

22. Bedse, G.; Di Domenico, F.; Serviddio, G.; Cassano, T. Aberrant insulin signaling in Alzheimer's disease: Current knowledge. Front. Neurosci. 2015, 9, 204. [CrossRef] [PubMed]

23. Devaskar, S.U.; Giddings, S.J.; Rajakumar, P.A.; Carnaghi, L.R.; Menon, R.K.; Zahm, D.S. Insulin gene expression and insulin synthesis in mammalian neuronal cells. J. Biol. Chem. 1994, 269, 8445-8454. [PubMed]

24. Kuwabara, T.; Kagalwala, M.N.; Onuma, Y.; Ito, Y.; Warashina, M.; Terashima, K.; Sanosaka, T.; Nakashima, K.; Gage, F.H.; Asashima, M. Insulin biosynthesis in neuronal progenitors derived from adult hippocampus and the olfactory bulb. EMBO Mol. Med. 2011, 3, 742-754. [CrossRef] [PubMed]

25. Banks, W.A.; Owen, J.B.; Erickson, M.A. Insulin in the brain: There and back again. Pharm. Ther. 2012, 136, 82-93. [CrossRef] [PubMed]

26. Le Roith, D.; Hendricks, S.A.; Lesniak, M.A.; Rishi, S.; Becker, K.L.; Havrankova, J.; Rosenzweig, J.L.; Brownstein, M.J.; Roth, J. Insulin in brain and other extrapancreatic tissues of vertebrates and nonvertebrates. Adv. Metab. Disord. 1983, 10, 303-340. [PubMed]

27. Kar, S.; Chabot, J.G.; Quirion, R. Quantitative autoradiographic localization of [125I] insulin-like growth factor I, [125I] insulin-like growth factor II, and [125I] insulin receptor binding sites in developing and adult rat brain. J. Comp. Neurol. 1993, 333, 375-397. [CrossRef] [PubMed]

28. O'Kusky, J.; Ye, P. Neurodevelopmental effects of insulin-like growth factor signaling. Front. Neuroendocrinol. 2012, 33, 230-251. [CrossRef] [PubMed]

29. Talbot, K.; Wang, H.Y.; Kazi, H.; Han, L.Y.; Bakshi, K.P.; Stucky, A.; Fuino, R.L.; Kawaguchi, K.R.; Samoyedny, A.J.; Wilson, R.S.; et al. Demonstrated brain insulin resistance in Alzheimer's disease patients is associated with IGF-1 resistance, IRS-1 dysregulation, and cognitive decline. J. Clin. Investig. 2012, 122, 1316-1338. [CrossRef] [PubMed] 
30. Bloemer, J.; Bhattacharya, S.; Amin, R.; Suppiramaniam, V. Impaired insulin signaling and mechanisms of memory loss. Prog. Mol. Biol. Transl. Sci. 2014, 121, 413-449. [PubMed]

31. Faria, J.A.; Kinote, A.; Ignacio-Souza, L.M.; de Araujo, T.M.; Razolli, D.S.; Doneda, D.L.; Paschoal, L.B.; Lellis-Santos, C.; Bertolini, G.L.; Velloso, L.A.; et al. Melatonin acts through MT1/MT2 receptors to activate hypothalamic Akt and suppress hepatic gluconeogenesis in rats. Am. J. Physiol. Endocrinol. Metab. 2013, 305, E230-E242. [CrossRef] [PubMed]

32. O'Neill, C. PI3-kinase/Akt/mTOR signaling: Impaired on/off switches in aging, cognitive decline and Alzheimer's disease. Exp. Gerontol. 2013, 48, 647-653. [CrossRef] [PubMed]

33. Kullmann, S.; Heni, M.; Veit, R.; Scheffler, K.; Machann, J.; Haring, H.U.; Fritsche, A.; Preissl, H. Selective insulin resistance in homeostatic and cognitive control brain areas in overweight and obese adults. Diabetes Care 2015, 38, 1044-1050. [CrossRef] [PubMed]

34. Zhu, X.; Perry, G.; Smith, M.A. Insulin signaling, diabetes mellitus and risk of Alzheimer disease. J. Alzheimer's Dis. 2005, 7, 81-84. [CrossRef]

35. Stanley, S.; Wynne, K.; McGowan, B.; Bloom, S. Hormonal regulation of food intake. Physiol. Rev. 2005, 85, 1131-1158. [CrossRef] [PubMed]

36. Baggio, L.L.; Drucker, D.J. Biology of incretins: GLP-1 and GIP. Gastroenterology 2007, 132, $2131-2157$. [CrossRef] [PubMed]

37. Varndell, I.M.; Bishop, A.E.; Sikri, K.L.; Uttenthal, L.O.; Bloom, S.R.; Polak, J.M. Localization of glucagon-like peptide (GLP) immunoreactants in human gut and pancreas using light and electron microscopic immunocytochemistry. J. Histochem. Cytochem. 1985, 33, 1080-1086. [CrossRef] [PubMed]

38. Holst, J.J.; Burcelin, R.; Nathanson, E. Neuroprotective properties of GLP-1: Theoretical and practical applications. Curr. Med. Res. Opin. 2011, 27, 547-558. [CrossRef] [PubMed]

39. Cork, S.C.; Richards, J.E.; Holt, M.K.; Gribble, F.M.; Reimann, F.; Trapp, S. Distribution and characterisation of Glucagon-like peptide-1 receptor expressing cells in the mouse brain. Mol. Metab. 2015, 4, 718-731. [CrossRef] [PubMed]

40. Abbas, T.; Faivre, E.; Holscher, C. Impairment of synaptic plasticity and memory formation in GLP-1 receptor KO mice: Interaction between type 2 diabetes and Alzheimer's disease. Behav. Brain Res. 2009, 205, $265-271$. [CrossRef] [PubMed]

41. Hamilton, A.; Patterson, S.; Porter, D.; Gault, V.A.; Holscher, C. Novel GLP-1 mimetics developed to treat type 2 diabetes promote progenitor cell proliferation in the brain. J. Neurosci. Res. 2011, 89, 481-489. [CrossRef] [PubMed]

42. McClean, P.L.; Parthsarathy, V.; Faivre, E.; Holscher, C. The diabetes drug liraglutide prevents degenerative processes in a mouse model of Alzheimer's disease. J. Neurosci. 2011, 31, 6587-6594. [CrossRef] [PubMed]

43. Hunter, K.; Holscher, C. Drugs developed to treat diabetes, liraglutide and lixisenatide, cross the blood brain barrier and enhance neurogenesis. BMC Neurosci. 2012, 13, 33. [CrossRef] [PubMed]

44. Hayes, M.R.; De Jonghe, B.C.; Kanoski, S.E. Role of the glucagon-like-peptide-1 receptor in the control of energy balance. Physiol. Behav. 2010, 100, 503-510. [CrossRef] [PubMed]

45. Williams, D.L.; Baskin, D.G.; Schwartz, M.W. Leptin regulation of the anorexic response to glucagon-like peptide-1 receptor stimulation. Diabetes 2006, 55, 3387-3393. [CrossRef] [PubMed]

46. Larsen, P.J.; Tang-Christensen, M.; Holst, J.J.; Orskov, C. Distribution of glucagon-like peptide-1 and other preproglucagon-derived peptides in the rat hypothalamus and brainstem. Neuroscience 1997, 77, 257-270. [CrossRef]

47. Vrang, N.; Larsen, P.J. Preproglucagon derived peptides GLP-1, GLP-2 and oxyntomodulin in the CNS: Role of peripherally secreted and centrally produced peptides. Prog. Neurobiol. 2010, 92, 442-462. [CrossRef] [PubMed]

48. Llewellyn-Smith, I.J.; Reimann, F.; Gribble, F.M.; Trapp, S. Preproglucagon neurons project widely to autonomic control areas in the mouse brain. Neuroscience 2011, 180, 111-121. [CrossRef] [PubMed]

49. Lovshin, J.A.; Drucker, D.J. Incretin-based therapies for type 2 diabetes mellitus. Nat. Rev. Endocrinol. 2009, 5, 262-269. [CrossRef] [PubMed]

50. Vella, A.; Shah, P.; Reed, A.S.; Adkins, A.S.; Basu, R.; Rizza, R.A. Lack of effect of exendin-4 and glucagon-like peptide-1-(7,36)-amide on insulin action in non-diabetic humans. Diabetologia 2002, 45, 1410-1415. [PubMed]

51. Oka, J.I.; Goto, N.; Kameyama, T. Glucagon-like peptide-1 modulates neuronal activity in the rat's hippocampus. Neuroreport 1999, 10, 1643-1646. [CrossRef] [PubMed] 
52. Isacson, R.; Nielsen, E.; Dannaeus, K.; Bertilsson, G.; Patrone, C.; Zachrisson, O.; Wikstrom, L. The glucagon-like peptide 1 receptor agonist exendin- 4 improves reference memory performance and decreases immobility in the forced swim test. Eur. J. Pharm. 2011, 650, 249-255. [CrossRef] [PubMed]

53. McClean, P.L.; Holscher, C. Liraglutide can reverse memory impairment, synaptic loss and reduce plaque load in aged APP/PS1 mice, a model of Alzheimer's disease. Neuropharmacology 2014, 76, 57-67. [CrossRef] [PubMed]

54. Hayes, M.R. Neuronal and intracellular signaling pathways mediating GLP-1 energy balance and glycemic effects. Physiol. Behav. 2012, 106, 413-416. [CrossRef] [PubMed]

55. Salcedo, I.; Tweedie, D.; Li, Y.; Greig, N.H. Neuroprotective and neurotrophic actions of glucagon-like peptide-1: An emerging opportunity to treat neurodegenerative and cerebrovascular disorders. Br. J. Pharm. 2012, 166, 1586-1599. [CrossRef] [PubMed]

56. Parthsarathy, V.; Holscher, C. Chronic treatment with the GLP1 analogue liraglutide increases cell proliferation and differentiation into neurons in an AD mouse model. PLoS ONE 2013, 8, e58784. [CrossRef] [PubMed]

57. Craft, S.; Baker, L.D.; Montine, T.J.; Minoshima, S.; Watson, G.S.; Claxton, A.; Arbuckle, M.; Callaghan, M.; Tsai, E.; Plymate, S.R.; et al. Intranasal insulin therapy for Alzheimer disease and amnestic mild cognitive impairment: A pilot clinical trial. Arch. Neurol. 2012, 69, 29-38. [CrossRef] [PubMed]

58. McClean, P.L.; Gault, V.A.; Harriott, P.; Holscher, C. Glucagon-like peptide-1 analogues enhance synaptic plasticity in the brain: A link between diabetes and Alzheimer's disease. Eur. J. Pharm. 2010, 630, 158-162. [CrossRef] [PubMed]

59. Darsalia, V.; Hua, S.; Larsson, M.; Mallard, C.; Nathanson, D.; Nystrom, T.; Sjoholm, A.; Johansson, M.E.; Patrone, C. Exendin-4 reduces ischemic brain injury in normal and aged type 2 diabetic mice and promotes microglial M2 polarization. PLoS ONE 2014, 9, e103114. [CrossRef] [PubMed]

60. Adamska, E.; Ostrowska, L.; Gorska, M.; Kretowski, A. The role of gastrointestinal hormones in the pathogenesis of obesity and type 2 diabetes. Przeglad Gastroenterol. 2014, 9, 69-76. [CrossRef] [PubMed]

61. Ravassa, S.; Beaumont, J.; Huerta, A.; Barba, J.; Coma-Canella, I.; Gonzalez, A.; Lopez, B.; Diez, J. Association of low GLP-1 with oxidative stress is related to cardiac disease and outcome in patients with type 2 diabetes mellitus: A pilot study. Free Radic. Biol. Med. 2015, 81, 1-12. [CrossRef] [PubMed]

62. Toft-Nielsen, M.B.; Damholt, M.B.; Madsbad, S.; Hilsted, L.M.; Hughes, T.E.; Michelsen, B.K.; Holst, J.J. Determinants of the impaired secretion of glucagon-like peptide- 1 in type 2 diabetic patients. J. Clin. Endocrinol. Metab. 2001, 86, 3717-3723. [CrossRef] [PubMed]

63. Vilsboll, T.; Krarup, T.; Deacon, C.F.; Madsbad, S.; Holst, J.J. Reduced postprandial concentrations of intact biologically active glucagon-like peptide 1 in type 2 diabetic patients. Diabetes 2001, 50, 609-613. [CrossRef] [PubMed]

64. Candeias, E.; Sebastiao, I.; Cardoso, S.; Carvalho, C.; Santos, M.S.; Oliveira, C.R.; Moreira, P.I.; Duarte, A.I. Brain GLP-1/IGF-1 Signaling and Autophagy Mediate Exendin-4 Protection Against Apoptosis in Type 2 Diabetic Rats. Mol. Neurobiol. 2017. [CrossRef] [PubMed]

65. Emsley, J.G.; Mitchell, B.D.; Kempermann, G.; Macklis, J.D. Adult neurogenesis and repair of the adult CNS with neural progenitors, precursors, and stem cells. Prog. Neurobiol. 2005, 75, 321-341. [CrossRef] [PubMed]

66. Hamilton, A.; Holscher, C. The effect of ageing on neurogenesis and oxidative stress in the APP(swe)/PS1(deltaE9) mouse model of Alzheimer's disease. Brain Res. 2012, 1449, 83-93. [CrossRef] [PubMed]

67. Cameron, H.A.; McKay, R.D. Adult neurogenesis produces a large pool of new granule cells in the dentate gyrus. J. Comp. Neurol. 2001, 435, 406-417. [CrossRef] [PubMed]

68. Abrous, D.N.; Koehl, M.; Le Moal, M. Adult neurogenesis: From precursors to network and physiology. Physiol. Rev. 2005, 85, 523-569. [CrossRef] [PubMed]

69. Bruel-Jungerman, E.; Davis, S.; Rampon, C.; Laroche, S. Long-term potentiation enhances neurogenesis in the adult dentate gyrus. J. Neurosci. 2006, 26, 5888-5893. [CrossRef] [PubMed]

70. Van Praag, H.; Shubert, T.; Zhao, C.; Gage, F.H. Exercise enhances learning and hippocampal neurogenesis in aged mice. J. Neurosci. 2005, 25, 8680-8685. [CrossRef] [PubMed]

71. Harkavyi, A.; Abuirmeileh, A.; Lever, R.; Kingsbury, A.E.; Biggs, C.S.; Whitton, P.S. Glucagon-like peptide 1 receptor stimulation reverses key deficits in distinct rodent models of Parkinson's disease. J. Neuroinflamm. 2008, 5, 19. [CrossRef] [PubMed] 
72. Faure, A.; Verret, L.; Bozon, B.; El Tayara, N.E.T.; Ly, M.; Kober, F.; Dhenain, M.; Rampon, C.; Delatour, B. Impaired neurogenesis, neuronal loss, and brain functional deficits in the APPxPS1-Ki mouse model of Alzheimer's disease. Neurobiol. Aging 2011, 32, 407-418. [CrossRef] [PubMed]

73. Bertilsson, G.; Patrone, C.; Zachrisson, O.; Andersson, A.; Dannaeus, K.; Heidrich, J.; Kortesmaa, J.; Mercer, A.; Nielsen, E.; Ronnholm, H.; et al. Peptide hormone exendin-4 stimulates subventricular zone neurogenesis in the adult rodent brain and induces recovery in an animal model of Parkinson's disease. J. Neurosci. Res. 2008, 86, 326-338. [CrossRef] [PubMed]

74. Drucker, D.J. Glucagon-like peptides: Regulators of cell proliferation, differentiation, and apoptosis. Mol. Endocrinol. 2003, 17, 161-171. [CrossRef] [PubMed]

75. During, M.J.; Cao, L.; Zuzga, D.S.; Francis, J.S.; Fitzsimons, H.L.; Jiao, X.; Bland, R.J.; Klugmann, M.; Banks, W.A.; Drucker, D.J.; et al. Glucagon-like peptide-1 receptor is involved in learning and neuroprotection. Nat. Med. 2003, 9, 1173-1179. [CrossRef] [PubMed]

76. Raber, J.; Rola, R.; LeFevour, A.; Morhardt, D.; Curley, J.; Mizumatsu, S.; VandenBerg, S.R.; Fike, J.R. Radiation-induced cognitive impairments are associated with changes in indicators of hippocampal neurogenesis. Radiat. Res. 2004, 162, 39-47. [CrossRef] [PubMed]

77. Snyder, J.S.; Hong, N.S.; McDonald, R.J.; Wojtowicz, J.M. A role for adult neurogenesis in spatial long-term memory. Neuroscience 2005, 130, 843-852. [CrossRef] [PubMed]

(C) 2017 by the authors. Licensee MDPI, Basel, Switzerland. This article is an open access article distributed under the terms and conditions of the Creative Commons Attribution (CC BY) license (http://creativecommons.org/licenses/by/4.0/). 